\title{
Do foreign direct investments accelerate economic growth? The case of the Republic of Macedonia
}

\section{Selma Kurtishi-Kastrati}

Faculty of Business,

American University of the Middle East,

Kuwait City, Kuwait

Email: selma.kurtishi-kastrati@aum.edu.kw

\section{Veland Ramadani*}

Faculty of Business and Economics,

South-East European University,

Tetovo, Macedonia

Email: v.ramadani@seeu.edu.mk

*Corresponding author

\section{Léo-Paul Dana}

Montpellier Business School,

Montpellier Research in Management,

2300 Avenue des Moulins, Montpellier, France

Email: lp.dana@supco-montpellier.fr

\section{Vanessa Ratten}

La Trobe Business School,

La Trobe University,

Melbourne, Australia

Email: v.ratten@latrobe.edu.au

\begin{abstract}
The aim of this paper is to examine the long-run and the short-run relationships between foreign direct investment (FDI) and economic growth in the Republic of Macedonia by applying the cointegration analysis and error correction model to identify the variables explaining FDI determinants in the Republic of Macedonia. The research further attempts to investigate the effect of FDI on economic growth of the Republic of Macedonia using the methodology of vector auto regression and Granger causality test in this specific country. Out of the general conclusions it is evident that despite the above-average growth rates in both gross domestic product (GDP) and FDI in the country, we have found that GDP does not seem to induce FDI and likewise, FDI seems not to induce GDP. It is possible that the nature of this relationship is influenced by other institutional and economic factors. The paper concludes by offering some suggestions to economic policy makers involved in FDI particularly those in transition economies and high-growth potential areas. Suggestions for future research and implications for practice are also stated in the paper.
\end{abstract}


Keywords: foreign direct investment; FDI; economic growth; cointegration analysis; error correction model; ECM; vector auto regression; VAR; Granger causality test; Macedonia.

Reference to this paper should be made as follows: Kurtishi-Kastrati, S., Ramadani, V., Dana, L-P. and Ratten, V. (2016) 'Do foreign direct investments accelerate economic growth? The case of the Republic of Macedonia', Int. J. Competitiveness, Vol. 1, No. 1, pp.71-98.

Biographical notes: Selma Kurtishi-Kastrati is an Assistant Professor of Business and Management at American University of the Middle East (AUM), Kuwait. Her courses at AUM are focused on management and leadership. Previously, she was a faculty member at Business and Economics Faculty at the South East European University. She received her BA in Business and International Management from Oxford Brookes University in Oxford, MA in International Business from Webster University, London and $\mathrm{PhD}$ in Foreign Direct Investments from South East European University. Her research interest includes international business, FDIs, business ethics and corporate social responsibility.

Veland Ramadani is an Associate Professor at South-East European University, Republic of Macedonia, where he teaches both undergraduate and postgraduate courses in entrepreneurship and small business management. His research interests include entrepreneurship, small business management and venture capital investments. He authored around 60 research articles and 12 text-books. $\mathrm{He}$ also serves as a member of editorial and reviewer board of several international journals.

Léo-Paul Dana is a Professor at Montpellier Business School and Marie Curie Fellow at Princeton University. He obtained his BA and MBA at McGill University and $\mathrm{PhD}$ from the Ecole des Hautes Etudes Commerciales HEC-Montréal. He served as the Deputy Director of the International Business MBA program at NTU in Singapore, and on the faculties of McGill University, INSEAD, and the University of Canterbury. He holds the title of Adjunct Professor at the University of Regina and the same at the University of the South Pacific. He has published extensively in a variety of journals including the British Food Journal, Cornell Quarterly, Entrepreneurship: Theory and Practice, Journal of Small Business Management, Journal of World Business and Small Business Economics.

Vanessa Ratten is an Associate Professor of Entrepreneurship and Innovation in the School of Management, La Trobe Business School. She has extensive experience in teaching and researching international business, management, marketing, entrepreneurship and innovation in both Australia and the USA. Her main research areas are sport entrepreneurship, international entrepreneurship and technology innovation. 


\section{Introduction}

In view of the fact that FDI together with trade, are the main vehicles for globalisation, failing to attract FDI can lead to the risks that a country, no matter how economically successful was in the past, may be taken away of the main sources of economic growth, namely capital, managerial and production capacity, job competitiveness and productivity (Bhensdadia and Dana, 2004; Lankes and Venables, 1996; Andersen, 1993). However, there are countries that do not participate in the process of globalisation or those who have inadequate or inferior policies compared to developed countries, hence run the risk of becoming reasonably less competitive in the global economy.

Foreign direct investments (FDIs) are considered the most important factors for economic growth of transition economies, including the Republic of Macedonia, by taking into account their numerous direct and indirect effects on domestic economy (see Estrin and Uvalic, 2014). FDIs "besides bringing in capital, it introduces new and modern technology, provides market opportunities and linkages to export, and help enhance the standard of living. Countries, in the modern era, can be observed competing with each other to come up with lucrative incentive plans in order to attract more and more FDIs" [Mohnot, (2007), p.159]. The Republic of Macedonia is one of the successor states of former Yugoslavia. It is a small country located in Central Balkan Peninsula, Southeast Europe. The Republic of Macedonia declared its independence on September 8, 1991, and became a member of the United Nations on April 8, 1993. As a result of a dispute with the southern neighbour, Greece, regarding the name issue, it was admitted under the provisional reference of the Former Yugoslav Republic of Macedonia, abbreviated as FYROM (United Nations, 1993; Ramadani et al., 2014). It covers $25,713 \mathrm{~km}^{2}$ (9,928 square miles), bordering Albania, Kosovo, Serbia, Bulgaria, and Greece. FDI in the Republic of Macedonia are considered as a crucial component for supporting the transition process and sustainable economic growth in the long run, since there is a lack of domestic capital and the low level of domestic savings.

This article focuses on the correlation between FDI and economic growth in the Republic of Macedonia. The statistics used in this study are taken from the International Financial Statistics. ${ }^{1}$

The gross domestic product (GDP) is selected to represent the economic growth; the variable FDI equals to FDI net inflows; and among other determinants of economic growth we choose to focus on employment as a percentage of total population, tertiary school enrolment is used as a proxy for human capital development; and the degree of trade openness which is measured by the share of the sum of export plus imports to GDP. The flow of the variables of interest, FDI and GDP, is shown in Figures 1 and 2 respectively.

The vast majority of FDI has been privatisation-related, with very little 'greenfield' investment in the form of new facilities. As it can be seen from Figure 1 once the privatisation process started, the inflow increased noticeably, reaching a peak of US\$ $447.1 \mathrm{ml}$. in 2001. The largest portion of this came from the privatisation of the telecommunications operator, Makedonski Telekomunikacii, which raised US\$ 310 million. In the following years FDI decreased subsequently because of the increased political risk and continuing weaknesses in the business environment. According to the State Statistical Office of the Republic of Macedonia ${ }^{2}$ and the National Bank of the Republic of Macedonia ${ }^{3}$, the cumulative value of FDI in the Republic of Macedonia at the end of 2002 was equivalent to approximately US\$ 105.6 million. 
The majority being accounted for by privatisation deals transacted through the Macedonian Stock Exchange. The trend enjoyed constant increase until 2004 reaching US\$ 323 million. By the end of 2005 the Republic of Macedonia had attracted inward investment of only US\$ 97 million, one of the lowest figures of any transition economy. Roughly half of all FDI in 2004 came from a large investment by Greek telecoms company OTE in the country's second mobile telephone company. In the first three quarters of 2005, inflows of FDI totalled over US\$ 88 million. Privatisation remains one of the key levers for attracting FDI into the Republic of Macedonia, and greenfield investments have been few and far between (Kurtishi-Kastrati, 2012). According to the UNCTAD World Investment Report (2008) the prospects are quite positive for the Republic of Macedonia and other countries in the region. The report notes that FDI flows to the countries of South-East Europe and the Commonwealth of Independent States increased in 2004 for the fourth consecutive year, reaching an all-time high of US\$ 323 million, and anticipates that growth is likely to continue in the near future. An FDI inflow worth of US\$ 97 million that was recorded in 2005 was very disappointing, since regional economies experienced significant injections of FDI. Nevertheless, the trend recovered dramatically in 2006 mainly due to the sale of the Electric Power Company (ESM Distribution) to EVN for US\$ 225 million. In 2007, just before the global economic crisis the Republic of Macedonia marked an all-time record when it attracted FDI worth US\$ 699.1 million as a result of which it enjoyed high GDP growth of $5 \%$ thus reflecting the improvement of macroeconomic conditions of the country. However, it followed by a sharp decrease in the subsequent years.

Figure 1 Flow of FDI in US\$ millions (see online version for colours)

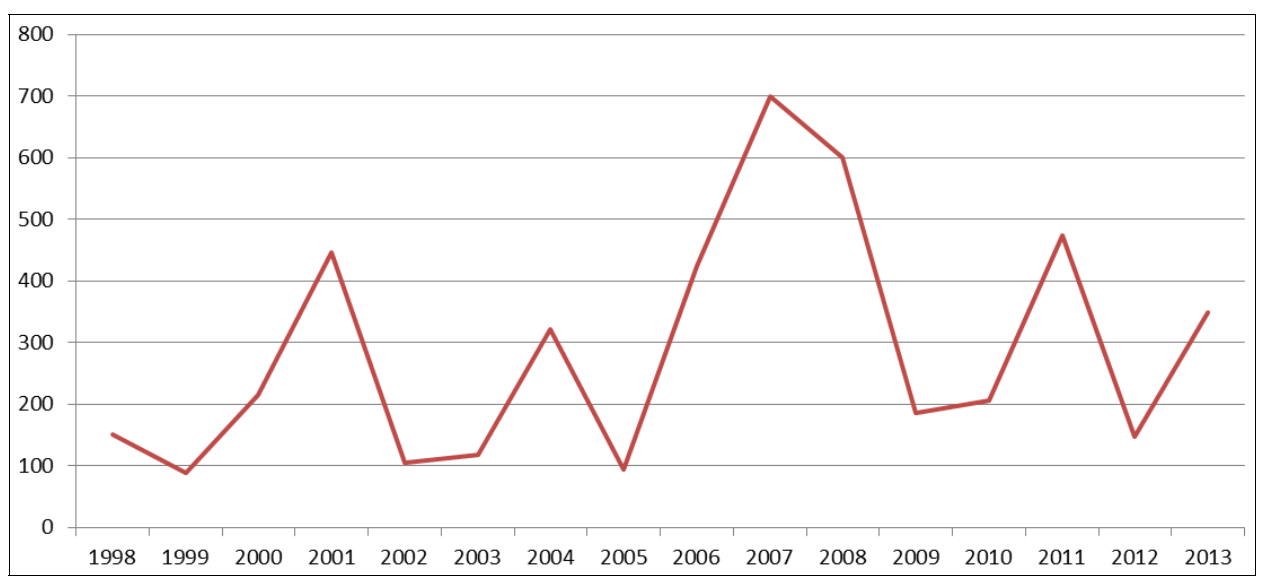

Source: National Bank of the Republic of Macedonia (1998-2013)

Figure 2 clearly shows the economy transition of the Republic of Macedonia for the last two decades. The initial transition process in the country started with unfavourable conditions for economic growth. Nonetheless these trends changed in parallel with other economic reforms. Considering that the 1990s were years of privatisation, opening the economy, change in the market structure, the Republic of Macedonia has been among the countries experiencing very turbulent and unstable economic growth. Economic output in country contracted sharply in the first few years of transition, and the country did not record positive real annual GDP growth until 1996. Growth remained modest until the 
end of the decade, as domestic demand grew slowly and foreign investment and financial assistance were unpredictable. The wars in former Yugoslavia, UN sanctions, the dispute with Greece and tension in Kosovo all deterred foreign trade and investment, since Serbia is both a major trading partner and an important transit route. The economy picked up at the end of the decade, expanding by $4.5 \%$ in 2000 , the fastest rate of growth since the independence. In 2001, during a civil conflict, the economy shrank to $-4.5 \%$ because of decreased trade, intermittent border closures, increased deficit spending on security needs, and investor uncertainty. During 2003-2006 the growth averaged 4\% per year and more than 5\% per year during 2007-2008 (Kurtishi-Kastrati, 2012).

Figure 2 Flow of GDP and GDP per capital growth in annual percent (see online version for colours)

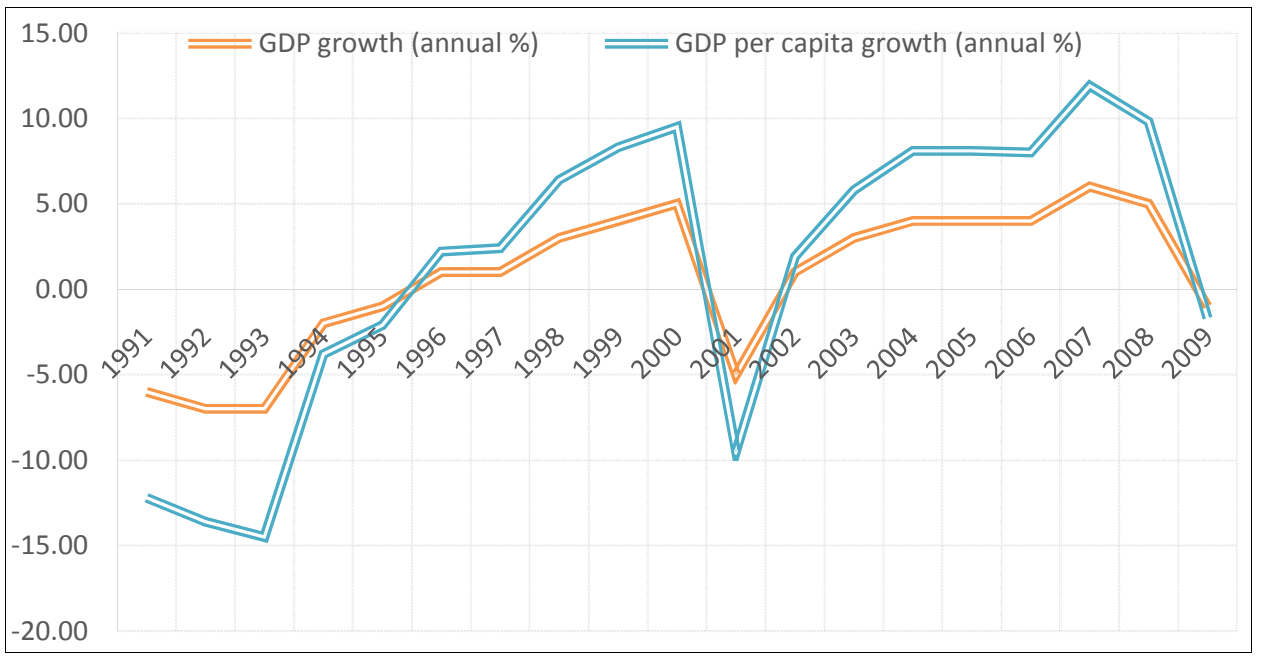

Source: National Bank of the Republic of Macedonia (1991 - 2009)

The Republic of Macedonia has maintained macroeconomic stability with low inflation, but it has so far lagged the region in attracting foreign investment and creating jobs, despite making extensive fiscal and business sector reforms. In the wake of the global economic downturn, the Republic of Macedonia has experienced decreased FDI, lowered credit, and a large trade deficit, but the financial system remained sound. Macroeconomic stability was maintained by a prudent monetary policy, which kept the domestic currency at the pegged level against the euro, at the expense of raising interest rates. As a result, GDP fell in 2009.

\section{Literature review}

Studying international transactions and activities never lose the actuality (see Ratten et al., 2007; Anandakumar, 2012). In this context, FDI always provoke interest among researchers (Nandi, 2011). A number of significant studies analysing the role FDI in stimulating economic growth have emerge during the last three decades. It was observed by several authors that the main reason for augmented effort in attracting more FDI has been determined from the idea that FDI has numerous positive effects (Carkovic and 
Levine, 2002; Caves, 1996; Agarwal and Ramaswami, 1992). It has been verified scientifically that foreign investment is more efficient in contributing to economic growth of the host country rather than domestic investment. According to De Gregorio (1992) in a panel data of 12 Latin American countries, it was revealed that FDI is three times more efficient than domestic investment. Important evidence that exists for the developed economies emerges to support the fact that productivity of domestic firms is positively related to the presence of foreign firms (Globerman, 1979). However, for developing economies, there are no clear results ${ }^{4}$. Nevertheless, there is a number of studies that finds positive spillover (Blomstrom et al., 1994; Kokko, 1994) and few of them reporting limited evidence (Aitken et al., 1997). The positions range from an unrestrained optimistic view (based on the neo-classical theory or, more recently, on the new theory of economic growth) to a systematic pessimism (namely among 'radical' economists). There is a widespread belief among researchers and policymakers that FDI boosts growth for host countries through different channels. They increase the capital stock and employment; stimulate technological change through the adoption of foreign technology and know-how and technological spillovers, which can happen via licensing agreements, imitation, employee training, and the introduction of new processes, and products by foreign firms. As it eases the transfer of technology, FDI is expected to increase and improve the existing stock of knowledge in the recipient economy through labour training, skill acquisition and diffusion. It contributes to introduce new management practices and a more efficient organisation of the production process. As a consequence, FDI can play an important role in modernising a national economy and promoting economic development.

Economic development is an all-inclusive concept; its main focus is on economic and social progress, in addition involves many different aspects that are not easily calculated, such as political freedom, social justice, and environmental reliability. Without a hesitation, all these matters bond together to contribute to an overall high standard of living. However, empirical evidence has sufficiently demonstrated that all these varied elements of economic development associate with economic growth. That is, as a general rule, countries with faster economic growth have more rapid improvement in health and education outcomes, progressively freer political system, increasingly more equitable distribution of wealth, and enhanced capacity for environmental management. Therefore, while economic growth does not bring about automatically other aspects of social, institutional and environmental improvements, without economic growth, there is a limited prospect for such achievements.

According to Rappaport (2000), FDI may improve the productivity not only of the firms receiving investments, but also of all firms of the host countries as a consequence of technological spillovers.

Johnson (2006) assumed that FDI should have a positive effect on economic growth as a result of technology spillovers and physical capital inflows. To test his assumption he used a panel of 90 countries and by performing both panel and cross-section analysis, he found that FDI inflows improve economic growth in developing economies, but not in developed economies. In addition, he also provides an outstanding review of the existing empirical literature on FDI and economic growth that summon macroeconomic data.

Moreover, Chowdhury and Mavrotas (2006) took a different route by testing for Granger (1969) causality using the Toda and Yamamoto (1995) specification, thereby overcoming possible pre-testing problems in relation to tests for co-integration between series. Using data from 1969-2000, according to their findings, FDI did not 
'Granger-cause' GDP in Chile, whereas there is a bi-directional causality between GDP and FDI in Malaysia and Thailand.

Hansen and Rand (2006) found strong causal link from FDI to GDP for a group 31 developing countries during 1970-2000. Blomstrom et al. (1994) found evidence that FDI caused economic growth. However, FDI's positive contribution is conditional. According to the authors, FDI is growth enhancing if the country is sufficiently reach measured in term of high per capita income.

Hsiao and Hsiao (2006) has examined the Granger causality relations between GDP, exports, and FDI among eight rapidly developing East and Southeast Asian economies using panel data from 1986 to 2004 . For the individual country time series causality tests, they did not find systematic causality among GDP, exports, and FDI variables. However, the panel data causality results reveal that FDI has unidirectional effects on GDP directly and indirectly through exports, and there also exists bidirectional causality between export and GDP for the group.

Jyun-Yi and Hsu (2008) analysed whether the FDI promote the economic growth by using threshold regression analysis. According to their analysis it shows that FDI alone play uncertain role in contributing to economic growth based on a sample of 62 countries during the period observed from 1975 to 2000 and find that initially GDP and human capital are important factor in explaining FDI. Further, FDI is found to have a positive and significant impact on growth when host countries have better level of initial GDP and human capital.

Falk (2009) examined the impact of FDI on economic growth of Pakistan, using data from 1980 to 2006 with variables of domestic capital, foreign owned capital and labour force. She concluded that FDI has negative statically insignificant relationship between GDP and FDI inflows in Pakistan by employing the endogenous growth theory and applying the regression analysis.

Some previous studies explained that there are also negative effects associated with FDI and economic growth. For instance, a research conducted by Haddad and Harrison (1993) test the spillover hypothesis for Moroccan manufacturing during 1985-1989. According to the authors, spillovers do not take place in all industrial sectors, and same as Blomström (1986), they find that foreign presence lowers the average flow of a sector's productivity, but they also examine that the effect is more significant in sectors with simpler technology. This is understood to signify that the presence of foreign companies forces local firms to become more productive in sectors where best practice technology lies within their capability, but that there are no significant transfers of modern technology. In addition, they find no considerable effects of foreign presence on the rate of productivity growth of local firms, and interpret this as additional support to the conclusion that technology spillovers do not take place. In contrary a positive effect is only dependent on the host economy's capacity to absorb them (Kokko, 1994).

According to the studies the impact FDI has on economic growth is far from being precise. Zhang (2001) in his work initiated that the role of FDI depends on the specifics of the country itself and the correlation with growth can either be positive, negative or irrelevant depending on the macroeconomic special considerations such as economic, institutional and technological conditions of the recipient country respectively. Due to the fact that there is no research done until now in the Republic of Macedonia for that reason we decided to investigate the impact of FDI $s$ on the economy since there is no clear perceptive of its involvement to growth. 


\subsection{Positive effects of FDIs}

FDI involve a complex of assets, which can be obtained only from the firms that create them. However, coping or reproducing these assets ('ownership advantages' of transnational corporations) by other companies especially in developing countries where advanced technologies are not available can be very costly. It is important to highlight that among the most valued proprietary assets probably belongs technology, than follows brand name, specialised skills and the ability to organise and integrate production across countries (Aizenman, 2005; Sathe and Handley-Schachler, 2006). All of these characteristics together mean that transnational corporations (TNCs) can contribute significantly to economic and social development in host countries - if host country can induce them to transfer their advantages in appropriate forms and at the same have adequate capability to make excellent use of them.

The positivity of FDI and its effects on the on the economy may be emphasised as follows (Kurtishi-Kastrati, 2012; Nayak, 2005; Bhensdadia and Dana, 2004):

- Capital-FDI brings in investible financial resources to host countries. In contrary to other source of capital, international companies usually invest in long-term project.

- Capital access - TNCs have better conditions in obtaining banking or other capital credits, at a lower cost than the purely domestic firm. According to Madura (1989, pp.11-17), the reason for this is due to the large opportunities set of funding sources around the world from which they can chose.

- Technology - Multinational companies can bring new and modern technologies and they can raise the efficiency with which existing technologies are used. These companies can stimulate technical efficiency and technical change in local firms, suppliers, clients and competitors, by providing assistance, by acting as role models and by intensifying competition.

- $\quad$ Market access - TNCs may certainly influence the access to exports markets for goods and services that are already produced in host countries, helping them switching from domestic to international markets. The benefits offered from export growth are in terms of technological learning, realisation of scale economies, competitive stimulus and market intelligence.

- Skills and management techniques - International companies employ and have worldwide access to individuals with advanced skills and knowledge and can transfer such skills and knowledge to their foreign affiliates by bringing in experts and by setting up state-of-art training facilities.

- Environment - TNCs are in the lead of developing clean technologies and modern environmental management systems. They use them in the counties where they operate.

- Enhancement of the institutional system of host countries - TNCs may have positive influence on development of institutional system of host country as effectives and competitiveness of markets, signal of reliability and the ongoing process of economic progress, protection and enforcement of property rights, enhancements in public administration procedures, and in general business climate. 
- $\quad$ TNCs can furthermore crowd in local (domestic) firms if they create strong connections with domestic suppliers and subcontractors. Crowding in can happen when the entry of TNCs increases business opportunities, increases investment and positively influences markets (making it more efficient). These stimulating effects take place mostly when FDI concentrates in industries that are undeveloped in host countries or the industries are new to the country.

According to the World Investment Report (2008), it concluded that although FDI can yield major economic benefits for the host country, such benefits can be enhanced through appropriate policies. According to Sohinger and Horvatin (2005, p.272), "the most visible, immediate, direct effects can be read off in the employment and exports statistics, and they are usually associated with greenfield or de novo investments in export oriented (manufacturing) sector. Indirect effects are much more subtle and they take time to manifest themselves. They work through a multiplicity of channels, and they create usually positive externalities for domestic producers". Governments of the host counties as a result have an important role to play in creating the conditions that attract FDI and in maximising the positive contribution that FDI can make to growth and development. Government also should intervene in the process of attracting FDI with measures to promote FDI generally or measures to promote specific types of FDI and to regulate and guide it. Government should choose between investments that offer short as opposed to long-term benefits; the former may lead to static gains but not necessarily to dynamic ones.

\subsection{Negative effects of FDIs}

Apart from it positive effects FDI has also its negatives which can be direct and indirect. These negativities associated with FDI and its effects on the economy may be determined as follows (Kurtishi-Kastrati, 2012):

- Hostile takeovers with intention to damp local production in that field so that foreign company would have no competition.

- Supporting foreign companies may lead to avoidance of local companies.

- Crowding out of domestic savings by foreign savings and forced transfer of domestic savings abroad under difficult conditions.

- Appreciation of a host country currency as a result of capital account surplus, which may cause a widening of trade balance deficit and liquidation of host county marginal exporters.

- High FDI inflows lead to increase in money supply and therefore resulting to inflationary effects. This will further lead to higher interest rates and insecure influence on a host county economy.

- Higher imports of raw materials and work in process of firms with foreign participation may result in liquidation of domestic suppliers.

- Repatriation of profit weighs down the current and capital account of balance of payments. 
- Lagging of domestic companies in comparison with foreign firms leads to a dual economy. In one hand, there are successful and expanding companies with foreign participation and on the other hand falling and hardly living domestic companies.

\section{Method}

In this part we examine the empirical relevance of several hypothesis put forward in the literature of FDI determinants, in order to explain the evolution of the aggregate FDI inflows received by the Macedonian economy during the 1994-2008 period. The reason for analysing the data for the specified period (1994-2004) was due to fact that in 2008 as a result of the financial crisis FDI on a global level suffered a considerable fall and by using the date after 2008 might not provide us with realistic empirical results.

One of the major objectives of this study was to examine, if there is any long run economic relationship between FDI and other variables used in this study. Cointegration analysis and error correction model (ECM) help us to investigate the relationship between these variables and to avoid the risk of spurious regression. Mainly, we want to identify the different variables, reflecting market seeking factors, resource seeking factors and efficiency seeking factors that determine the size FDI in the Republic of Macedonia. The cointegration techniques used in this study allow us to obtain robust and reliable estimates of the parameters in the empirical relationship. Following this approach we identify the long run determinants of FDI in the Republic of Macedonia over the period 1994-2008.

The general form of the model estimated has the following form:

$$
L N F D I=f(L N G D P, L N O P N, L N E M P, L N T S E)
$$

where

LNGDP GDP in millions of dollars, in logarithm

LNOPN (export + import) as a share of GDP, in logarithm

LNEMP employment, in logarithm

LNTSE total school enrolment in tertiary education as a share of host country population, in logarithm.

Given that the study covers the period 1994-2008, using quarterly data and the variables discussed in the earlier section, compose time series information, the appropriate modelling strategy is using time series analysis. The particular model can be specified by:

$$
L N F D I_{t}=a_{0}+B_{1} L N G D P_{t}+B_{2} L N O P_{t}+B_{3} L N E M P_{t}+B_{4} L_{N T S E}+u_{t}
$$

When estimating regression models using time series data it is necessary to know whether the variables are stationary or not (either around a level or a deterministic linear trend) in order to avoid spurious regression problems. So the first thing to do when performing the regression analysis of FDI determinants is to check for spurious regression. When using non-stationary time series in a regression model one may gain apparently significant relationships from unrelated variables. This phenomenon known as spurious regression or 'non-sense regressions' occur when results from the model show promising diagnostic test statistics even where the regression analysis has no meaning 
(Gujarat, 2003). To avoid this problem initial we check for the stationary of variables in any time series analysis.

\subsection{Unit root test - test for stationarity}

Macroeconomic time series are usually not stationary. Series are made stationary by calculating logarithms or taking first or second differences. There are many tests used to determine stationary. In our case, the stationary of the variables will be tested by using augmented Dickey-Fuller (ADF) unit root test. Stationarity is essentially a restriction on the data generating process over time. More specifically, stationarity means that the fundamental form of the data generating process remains the same over time. Stationary (weak) is a characteristic of time series data, when the mean, variance and covariance are time independent (covariance being dependent on the length of the lag, but not the time, in which it is observed). In other words covariance stationarity means that the serial correlation of two observations $\left\{Y_{t}, Y_{t+s}\right\}$ depends only on the lag $s$ and not on 'where' in the series they fall. Hence, this is called weak stationarity (stationarity in the moments). A stricter form of stationarity requires that the joint probability distribution (all the moments) of series of observations $\left\{Y_{1}, Y_{2}, \ldots, Y_{t}\right\}$ is the same as that for $\left\{Y_{1+s}\right.$, $\left.Y_{2+s}, \ldots, Y_{t+s}\right\}$ for all $t$ and $s$. It is essential to test for stationarity to confirm that the process by which data could have been generated is a stochastic one.

Hence, in conducting the Dickey-Fuller test on equation (2), it is assumed that the error term $u_{t}$ is uncorrelated. In the cases when $u_{t}$ are correlated, Dickey and Fuller have developed another test, known as the ADF test. The starting point in unit root test is:

$$
Y_{t}=a Y_{t-1}+u_{t} ; \quad-1 \leq a \leq 1
$$

The null hypothesis in the ADF test is that the underlying process which generated the time series in non-stationary. This will be tested against the alternative hypothesis that the time-series information of interest is stationary. If the null hypothesis is rejected, it means that the series is stationary i.e. it is integrated to order zero. If, on the other hand, the series is non-stationary, it is integrated to a higher order and must be differenced till it becomes stationary. The order of integration of a time series dataset shows the number of times the series has to be differenced before it becomes stationary (Gujarat, 2003). When testing for unit root we want to find out whether $a$ in the equation (3) is equal to 1 . If $a$ is smaller then 1, the series is stationary. If, on the other hand, $a$ is greater than 1 , than it would be an explosive series.

$$
\begin{aligned}
& Y_{t}-Y_{t-1}=(a-1) Y_{t-1}+u_{t} \\
& \Delta Y_{t}=\beta Y_{t-1}+u_{t}
\end{aligned}
$$

Subtracting $Y_{t-1}$ from both sides we get equation (4), which is estimated by the Dickey-Fuller and ADF test. In addition a constant - testing for a random walk with drift, and time trend - testing for a deterministic feature, are incorporated into the equation (4). Since the null hypothesis in equation (3) is that $a$ is equal to 1 , in equation (4) it must be that $\beta$ is equal to zero. Hence, when $\beta$ is zero, there is unit root, and we have insufficient evidence to reject the null hypothesis of non-stationarity. When the series becomes stationary things that happened recently are relatively more important than things that happened a long time ago. On the other hand, when we have non-stationary time series things that occurred a long time ago have a large impact compared to things that occurred 
more recently. In order to test for the stationarity of time series, we have to difference the variables. We start with the plot of logarithmic values of explanatory variables. The plot of logarithmic variables will give the identical results, because the logarithmic is a monotonic transformation.

Figure 3 Plot LNGDPMD (see online version for colours)

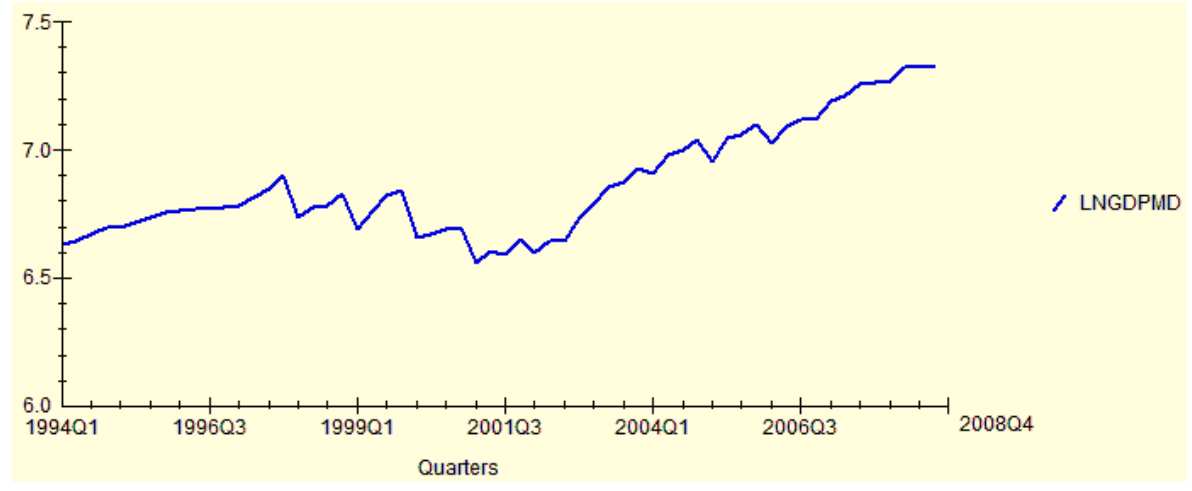

Figure 4 Plot DLNGDPMD (see online version for colours)

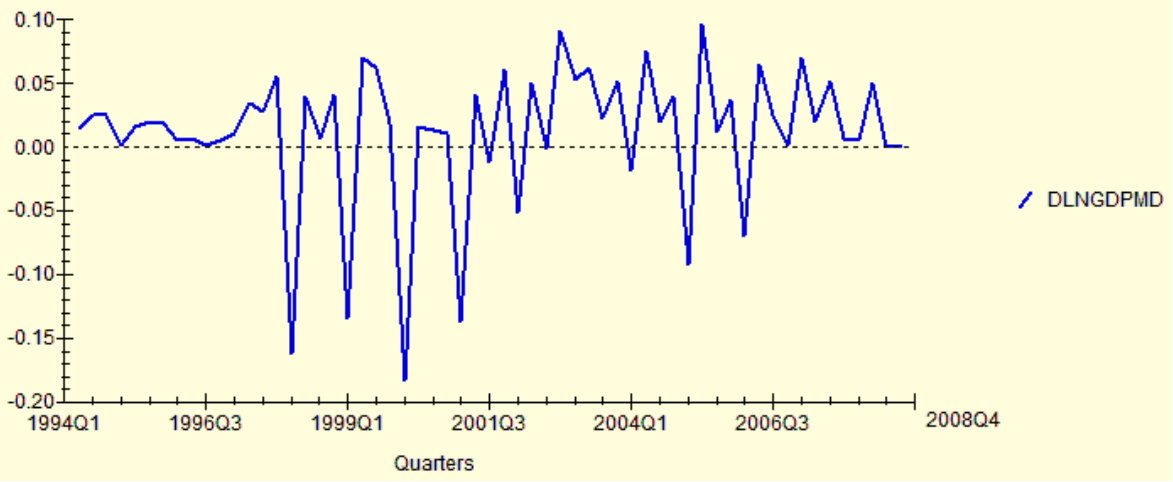

Figure 5 Plot DDLNGDPMD (see online version for colours)

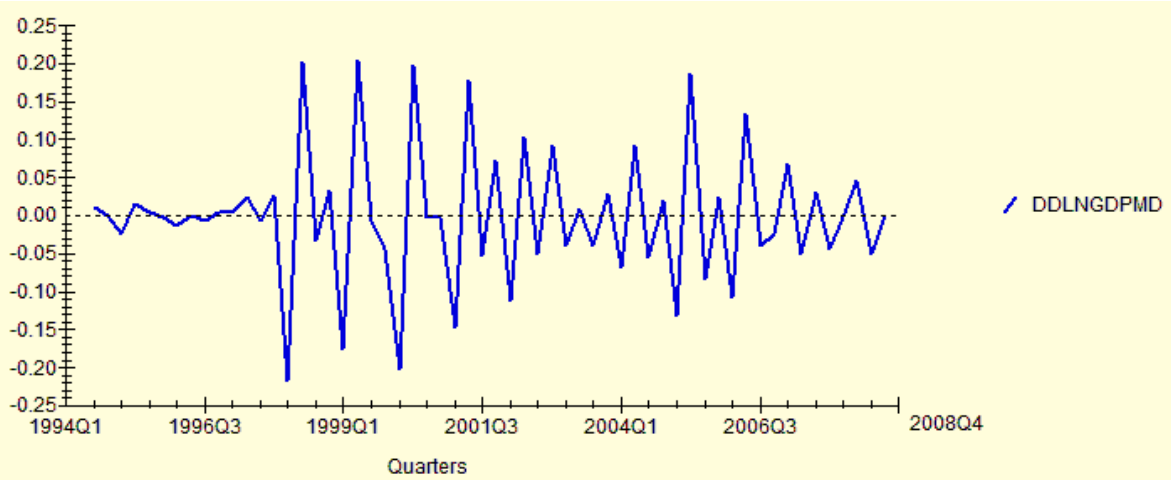


Figure 6 Plot LNIOP (see online version for colours)

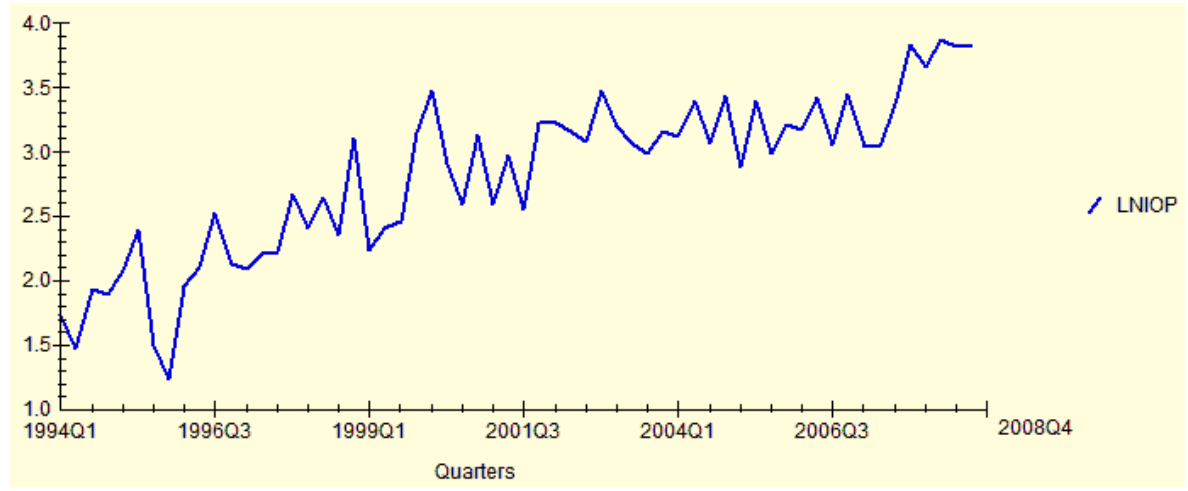

Figure 7 Plot DLNIOP (see online version for colours)

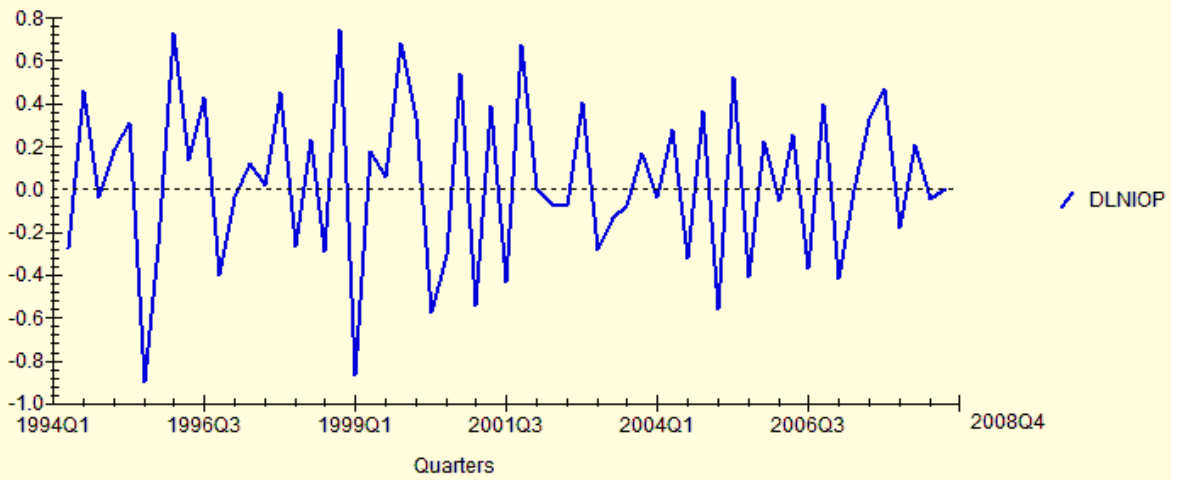

Figure 8 Plot LNEM (see online version for colours)

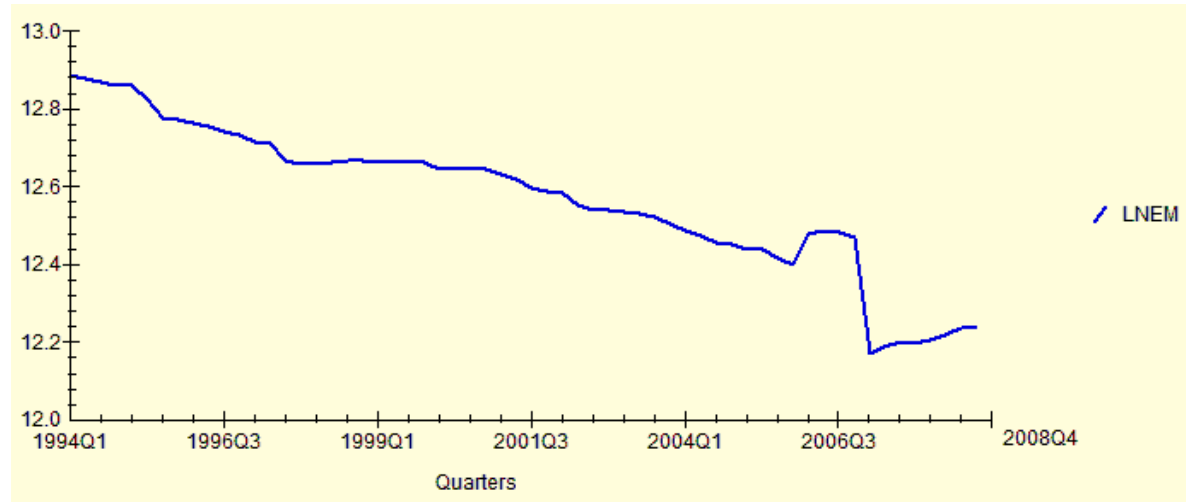


Figure 9 Plot DLNEM (see online version for colours)

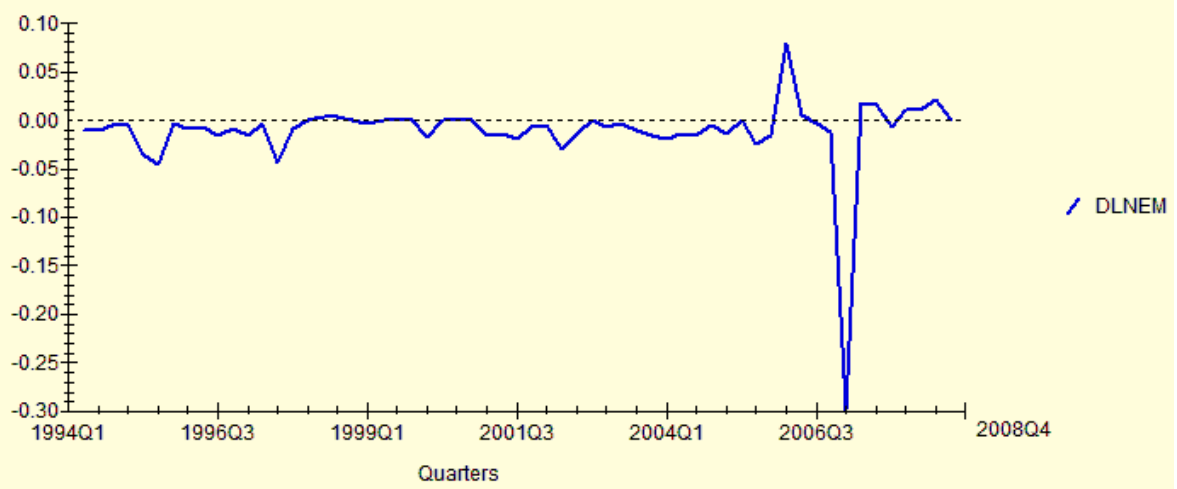

Figure 10 Plot LNTSE (see online version for colours)

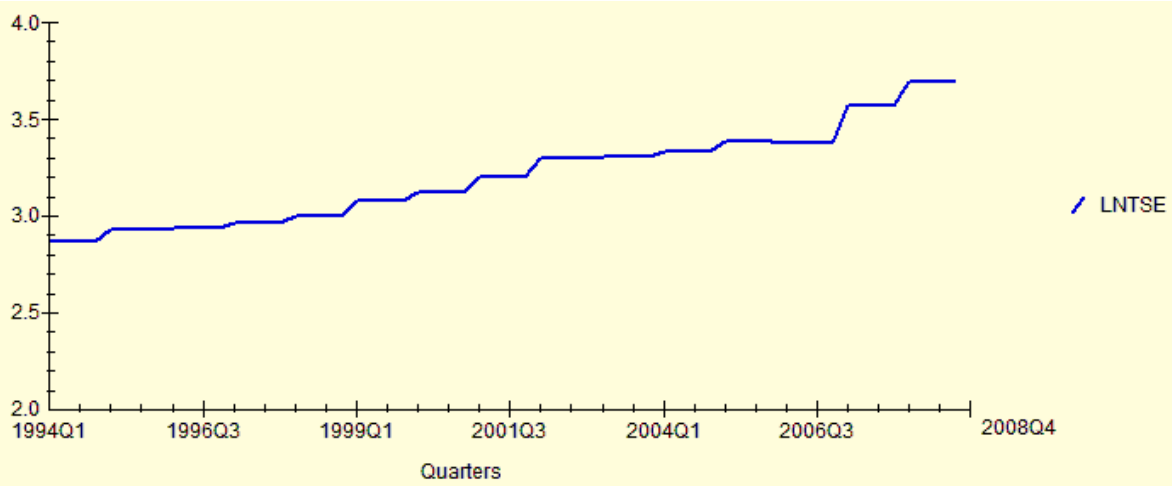

Figure 11 Plot DLNTSE (see online version for colours)

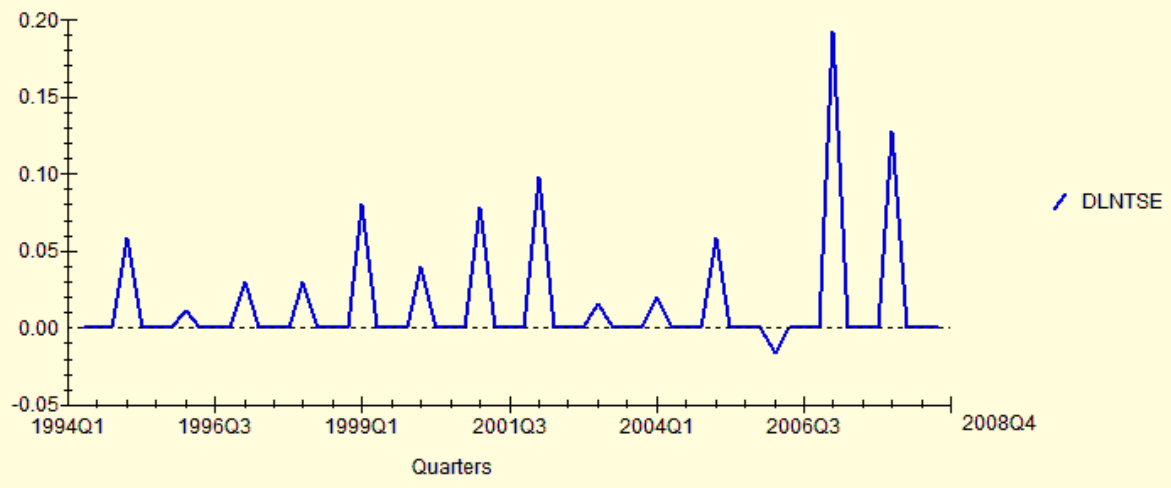


Figure 12 Plot DDLNTSE (see online version for colours)

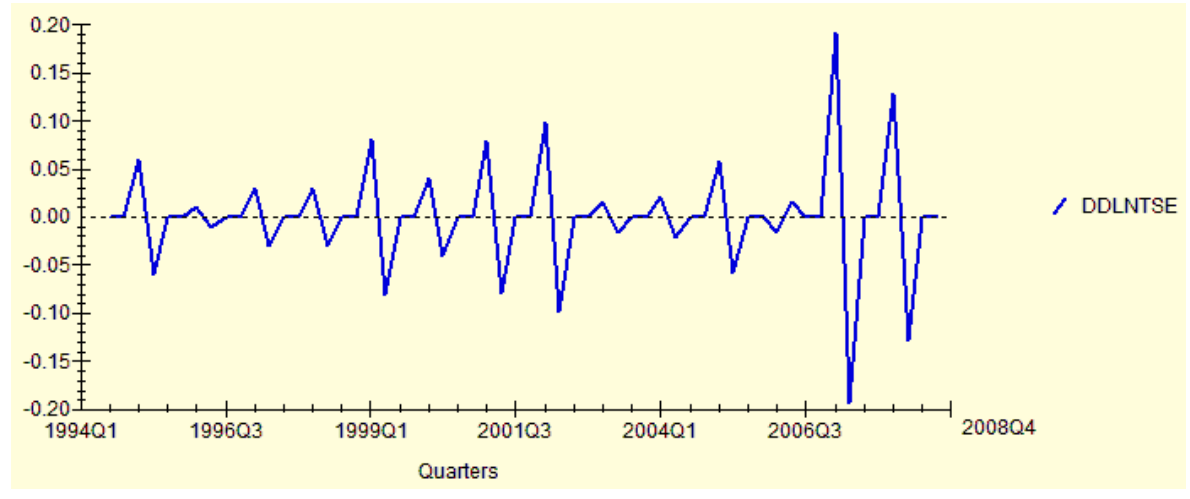

From Figures 3-12, it can be noticed that the explanatory variables of employment and openness are becoming stationary after first differencing, while the variables of GDP and total school enrolment of host country population as a share of gross total population are becoming stationary after second differencing. The dependent variable of FDI is becoming stationary after first differencing. This means that the null hypothesis that a given series contain a unit root and is non-stationary, was rejected for the first differences for the variables of employment and openness, while for the variables of GDP and Schooling, the null hypothesis that a given series contain a unit root and is non-stationary, was rejected after the second differencing. The results of the ADF tests are shown in Table 1. The same conclusion is achieved, on the following table, when comparing the $\mathrm{t}$ statistics with their critical values.

The test of stationarity and co integration that we have performed, suggest that the model (2) should be estimated, using the differenced variables. Hence, we can only look at a short run relationship among these variables (Gujarat, 2003). The final short run model estimated has the following form.

$$
\begin{aligned}
\Delta L N F D I M L D_{t}= & a_{0}+B_{1} \Delta \Delta L N G D P_{t}+B_{2} \Delta L N O P_{t} \\
& +B_{3} \Delta \Delta L N T S E_{t}+B_{4} \Delta L N E M_{t}+\varepsilon_{t}
\end{aligned}
$$

$\Delta$ denote the first difference of the variable.

After determining the order of integration of the variables, we followed the two-step estimation procedure for dynamic modelling suggested by Engle and Granger (1987). So, in a first step the so-called 'cointegrating regression', in which all the variables would be in levels and no dynamics included, would be estimated by ordinary least squares (OLS), and the residuals from this regression will be tested for the presence of a unit root (Bajo-Rubio and Sosvilla-Rivero, 1994). If the residuals were found to be stationary, the co-integrating regression might be taken as a long-run relationship and we could then proceed to the second step, where an ECM, including those lagged residuals as an error-correction term would be postulated in order to consider the short-run dynamics. When we test for the presence of unit root on the residuals obtained, after OLS estimation of the equation (2), we find that the residuals are stationary. 
Table 1 ADF - unit root test

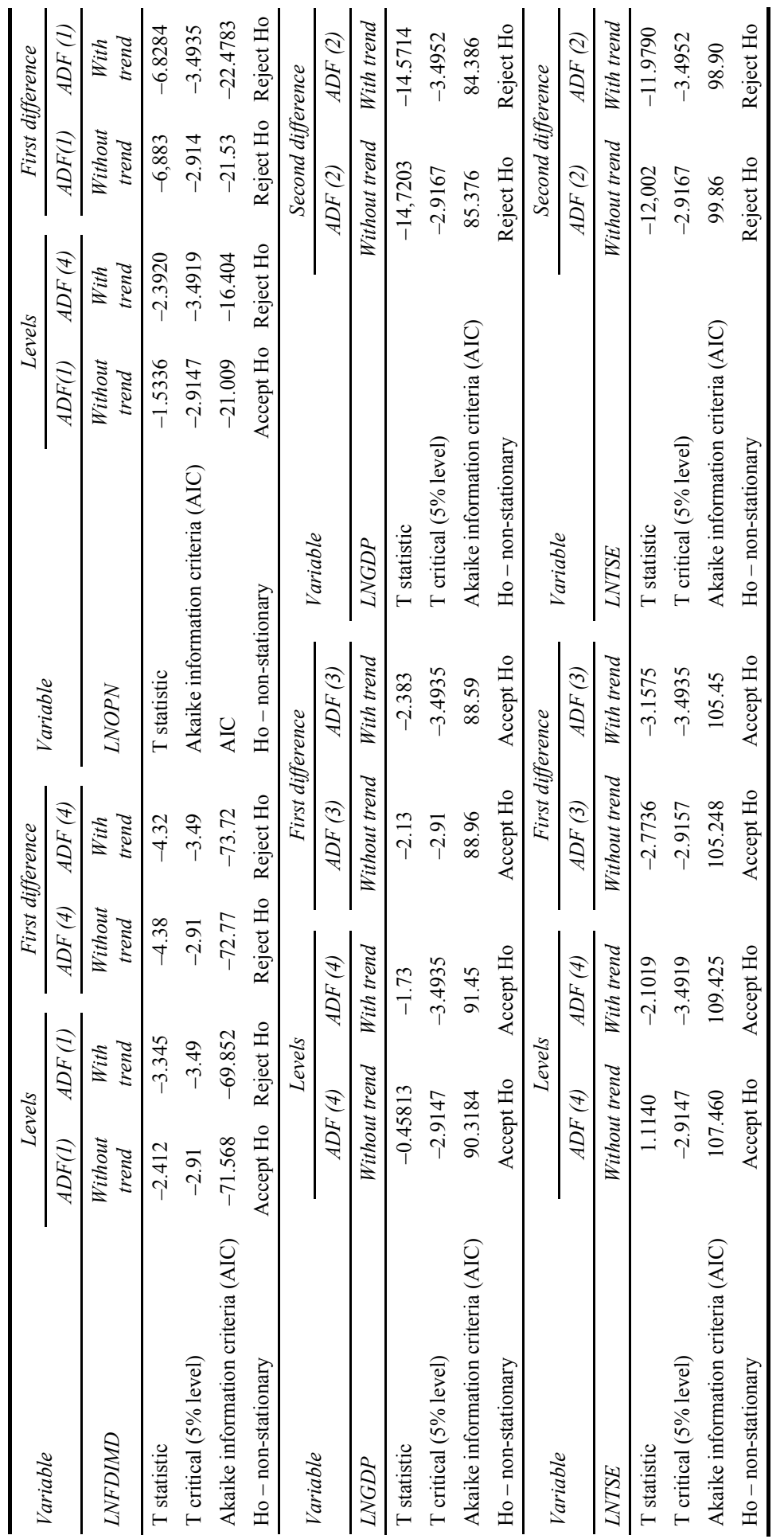


Table 2 The unit root tests results on residuals from the regression in levels - Engle Granger method

\begin{tabular}{|c|c|c|c|c|}
\hline \multicolumn{5}{|c|}{ The Dickey-Fuller regression } \\
\hline \multicolumn{5}{|c|}{ Based on OLS regression of $L N F D I M L D$ on: C LNGDP LNIOP LNEMP LNTSE } \\
\hline \multicolumn{5}{|c|}{53 observations used in the estimation of all ADF regressions. } \\
\hline \multicolumn{5}{|c|}{ Sample period from 1995Q4 to 2008Q4 } \\
\hline & \multicolumn{2}{|c|}{$D F$} & \multicolumn{2}{|c|}{$A D F(4)$} \\
\hline Without trend (ADF 4) & -5.7294 & $(-2.9167)$ & -2.9710 & $(-2.9167)$ \\
\hline With trend (ADF 1) & -5.6678 & $(-3.4952)$ & -3.8917 & $(-3.4952)$ \\
\hline
\end{tabular}

Note: $95 \%$ critical values in brackets.

From Table 2, we see that $t$ statistic exceeds the critical value, signifying no unit root. The residuals are stationary, thus confirming, the presence of the long run relationship between the variables. The series are cointegrated and therefore we proceed with the second step, by analysing the error correction mechanism, thus enhancing the approach of non-stationary time series.

\subsection{Error correction mechanism}

The term 'ECM' applies to any model that directly estimates the rate at which changes in $Y_{t}$ return to equilibrium after a change in $X_{t}$. The EC model has a nice behavioural justification in that it implies that the behaviour of $Y_{t}$ is tied to $X_{t}$ in the long run and that short run changes in $\mathrm{Yt}$ respond to deviations from that long run equilibrium. In order to make a formal analysis of cointegration approach, we employ the second step of estimation procedure for dynamic modelling suggested by Engle and Granger (1987). Hence, in order to model the long run dynamics, when estimating the final short run model [equation (5)], suggested by ADF test, we consider the postulation of the lagged residuals as an error correction term, obtained from the OLS estimation of equation (2). Following this approach we estimate the cointegration regression shown on equation (7), which confirms the presence of long run relationships between the explanatory variables (Gujarat, 2003).

The ECM is as follows.

$$
\Delta Y=B_{0}+B_{1} \Delta X_{t}+B_{2}\left(Y_{t-1}-C-X_{t-1}\right)+\varepsilon_{t}
$$

where

$u_{t}-1=\left(Y_{t-1}-C-X_{t-1}\right)+\varepsilon \quad$ error correction mechanism

Initial we estimate error correction mechanism from cointegraiting regression; we lag it, and then run the following regression.

$$
\begin{aligned}
\Delta L N F D I M L D_{t}= & a_{0}+B_{1} \Delta \Delta G D P_{t}+B_{2} \Delta L N O P N_{t} \\
& +B_{3} \Delta L N E M P_{t}+B_{4} \Delta \Delta L N T S E+B_{5} u_{t-1}
\end{aligned}
$$

$u_{t-1}$ denote the error correction term. 
Since the model was estimated in logarithm the estimated coefficients denote elasticity's. Following this procedure, the results of applying the ECM procedure to equation (7) for total FDI were as follows.

$$
\begin{aligned}
& D D L N F D I M D=-0.051-0.76 D D L N G D P-7.35 D L N E M+0.99 D L N I O P \\
& \text { T-statistic (-4.7) (5.65) (-24.99) } \\
& \text {-0.89DDLNTSE + 1.0027 RES } 2 \\
& (-3.76) \quad(97.15)
\end{aligned}
$$

\begin{tabular}{|c|c|c|c|}
\hline \multicolumn{4}{|c|}{$\begin{array}{l}\text { Error correction mechanism. final estimation obtained from last equation - } \\
\text { ordinary least squares estimation }\end{array}$} \\
\hline \multicolumn{4}{|c|}{ Dependent variable is DLNFDIMD } \\
\hline \multicolumn{4}{|c|}{57 observations used for estimation from 1994Q4 to 2008Q4 } \\
\hline Regressor & Coefficient & Standard error & T-ratio (prob) \\
\hline $\mathrm{C}$ & -.051145 & .010694 & $4.7827[.000]$ \\
\hline DDLNGDPMD & -.76662 & .13568 & $5.6504[.000]$ \\
\hline DLNEM & -7.3503 & .29406 & $24.9959[.000]$ \\
\hline DLNIOP & .99599 & .029783 & $33.4421[.000]$ \\
\hline DDLNTSE & -.89105 & .23671 & $3.7643[.000]$ \\
\hline R2 & 1.0027 & .010321 & $97.1598[.000]$ \\
\hline R-squared & .99486 & R-bar-squared & .99436 \\
\hline S.E. of regression & .076116 & F-stat. & $\mathrm{F}(5,51) 1,974.2[.000]$ \\
\hline Mean of dependent variable & .041077 & S.D. of dep. variable & 1.0132 \\
\hline Residual sum of squares & .29547 & Equation log-likelihood & 69.0939 \\
\hline AIC & 63.0939 & Schwarz Bayesian criterion & 56.9648 \\
\hline DW-statistic & 1.2571 & & 97.15 \\
\hline \multicolumn{4}{|c|}{ Diagnostic tests } \\
\hline Test statistics & & $L M$ version & $F$ version \\
\hline A: Serial correlation & CHS & $\mathrm{Q}(4)=19.4756[.001]$ & $F(4,47)=6.0984[.000]$ \\
\hline B: Functional form & $\mathrm{CHS}$ & $\mathrm{Q}(1)=.93090[.335]$ & $\mathrm{F}(1,50)=.83014[.367]$ \\
\hline C: Normality & CHS & $\mathrm{Q}(2)=24.5313[.000]$ & Not applicable \\
\hline D: Heteroscedasticity & $\mathrm{CHS}$ & $\mathrm{Q}(1)=.16654[.683]$ & $\mathrm{F}(1,55)=.16117[.690]$ \\
\hline
\end{tabular}

Table 3 Results from cointegration regression, derived from ECM procedure [equation (7)], including the lagged residuals obtained from OLS estimation of equation (2)

Notes: A: Lagrange multiplier test of residual serial correlation

B: Ramsey's RESET test using the square of the fitted values

$\mathrm{C}$ : Based on a test of skewness and kurtosis of residuals

D: Based on the regression of squared residuals on squared fitted values

\subsection{Interpretation of the results from cointegration regression (vector error correction mechanism)}

From the above results obtained from error correction mechanism regression, we see that all the variables determining FDIs in the Republic of Macedonia are statistically 
significant. The coefficient of RES 2, shows how fast is the changes in the explanatory variables per unit change of the dependent variable. The intercept is statistically insignificant, while the error correction mechanism that implies long run equilibrium relationship is statistically significant at $1 \%$ level.

The market seeking variable denoted by GDP, contrary to expectations is found to be critical factor on capital accumulation in the Republic of Macedonia, in the form of FDI. This is due to the fact that growth rate of the GDP in the Republic of Macedonia is greater than the growth rate of the stock FDI. In the model, holding other variables constant, for each percentage increase in GDP growth, the net FDI as a share of GDP decreases by $0.76 \%$. This relationship is due to the reasons this country, during the analysed period was in the process of installing parliamentary democracy, and this result, has been attributed to deficit financing of the democratic process (Frimpong and Oteng-Abayie, 2008). Meaning that the growth is mainly reflecting government sector deficit financing rather than the growth of real sector. Similar result suggesting the negative relationship between FDI and GDP growth has been found by Frimpong and Oteng-Abayie (2008), when analysing bivariate causality between FDI inflows and economic growth in Ghana.

Employment is found to be significant factor determining FDI, laying on a negative relationship with it. The results indicate that, one percent increase in employment level; will lead to, an average $7.35 \%$ decrease on FDIs. This contrary result may be attributed to low skilled workers and staff with insufficient knowledge for applying the appropriate performance, during their job, thus unsatisfying the demand of foreign enterprises to invest in the country. Similar result was found by Dauti (2009).

With regard to openness level of economy, measured by exports plus imports over GDP, the results indicate that FDIs in the Republic of Macedonia are determined also by significant openness degree of the state. Holding other variables constant, each percentage increase in the openness degree of Macedonian economy, will lead to, on average 0.99 percentage increase of cumulative FDI. This result is particularly important for Macedonian economy, once considering the effort of Macedonian economy for trade liberalisation and its ambitions for becoming part of EU and EMU countries.

Schooling variable, capturing efficiency seeking consideration is found to be significant factor on determining FDI in Macedonia, laying on negative relationship with FDI, meaning that enrolment of host country population on tertiary education is insufficient evidence for foreign investors, to be considered. Therefore the quality of tertiary education is not a good signal for foreign investors to consider an investment action in the Republic of Macedonia.

\subsection{A causality analysis}

According to Granger (1969), $\mathrm{Y}$ is said to 'Granger-cause' $\mathrm{X}$ if and only if $\mathrm{X}$ is better predicted by using the past values of $\mathrm{Y}$ than by not doing so with the past values of $\mathrm{X}$ being used in either case. In short:

1 if a scalar $Y$ can help to forecast another scalar $X$, then we say that $Y$ Granger-causes $\mathrm{X}$

2 if $\mathrm{Y}$ causes $\mathrm{X}$ and $\mathrm{X}$ does not cause $\mathrm{Y}$, it is said that unidirectional causality exists from $\mathrm{Y}$ to $\mathrm{X}$ 
3 if $\mathrm{Y}$ does not cause $\mathrm{X}$ and $\mathrm{X}$ does not cause $\mathrm{Y}$, then $\mathrm{X}$ and $\mathrm{Y}$ are statistically independent

4 if $\mathrm{Y}$ causes $\mathrm{X}$ and $\mathrm{X}$ causes $\mathrm{Y}$, it is said that feedback exists between $\mathrm{X}$ and $\mathrm{Y}$.

Essentially, Granger's definition of causality is framed in terms of predictability.

With the regression analysis we want to estimate whether FDI promotes economic growth in the Republic of Macedonia and whether GDP can encourage the level of FDI. Namely, we want to find out if the changes in the level of GDP will respond with changes in the level FDI.

In order to test for direct causality between FDI and economic growth, we perform a Granger causality test using the following equations:

$$
\begin{aligned}
& Y_{t}=\alpha_{0}+\sum_{i=1}^{k_{1}} \alpha_{i} Y_{t-i}+\sum_{i=1}^{k_{2}} \beta_{i} X_{t-i}+\varepsilon_{t} \\
& X_{t}=\gamma_{0}+\sum_{i=1}^{k_{2}} \gamma_{i} Y_{t-i}+\sum_{i=1}^{k_{4}} \delta_{i} X_{t-i}+\phi_{t}
\end{aligned}
$$

The granger causality test applied for the relationship between FDI and GDP is as follows:

$$
\begin{aligned}
& G D P_{t}=\gamma+\sum_{i=1}^{k} \alpha_{i} \cdot G D P_{t-i}+\sum_{i=1}^{k} \beta_{i} \cdot F D I_{t-i}+\mu_{t} \\
& F D I_{t}=\phi+\sum_{i=1}^{k} \delta_{i} \cdot G D P_{t-i}+\sum_{i=1}^{k} \lambda_{i} \cdot F D I_{t-i}+\eta_{t}
\end{aligned}
$$

where $G D P_{t}$ and $F D I_{t}$ are stationary time series sequences, $\gamma$ and $\phi$ are the respective intercepts, $\mu_{t}$ and $\eta_{t}$ are white noise error terms, and $k$ is the maximum lag length used in each time series. The optimum lag length is identified using Hsiao's (1981) sequential procedure, which is based on Granger's definition of causality and Akaike's (1969) minimum final prediction error criterion. If in equation (11) $\sum_{i=1}^{k} \beta_{i}$ is significantly different from zero, then we conclude that FDI Granger causes GDP. Separately, if $\sum_{i=1}^{k} \delta_{i}$ in equation (12) is significantly different from zero, then we conclude that GDP Granger causes FDI. Granger causality in both directions is, of course, a possibility.

\section{Discussion of the results}

\subsection{Results from vector auto regression model}

In order to make a more formal analysis of the influence of GDP on FDI and the influence of the lagged value of FDI on further capital inflow, we apply the methodology of vector auto regression (VAR). The analysed period is from the first quarter 1994 to the fourth quarter 2008. In the specification of the model, when we consider FDI as dependent variable, the results showed that statistically significant are the changes in the 
first time lag of FDI and GDP in level. Therefore, the VAR results of the first equation based on only one lag of the endogenous variable of FDI. The model set in this manner gives satisfied explanation for the relation between the changes in GDP and the changes in FDI at the first lag, which is evident from the R square from 0.997 . The coefficient of GDP is highly significant at $1 \%$ level, (indicated by $p$ value of 0.000 ), with regard to the changes in FDI (which points to high dependency rate of the FDI flows from the economic development of the Macedonian economy). The coefficient of the first lagged value of FDI, is also highly significant at $10 \%$ level of significance (indicated by $p$ value of 0.051). Thus, according to the VAR model, it is assumed that, on average if GDP is increased by 1 million dollar, FDI, on average, would be increased by 0.47 million dollars. At the same time, on average the increase of FDI in the current year, will be followed by increase of Foreign capital in the further year 0.24 million dollar. On the other hand, when applying VAR analysis for equation (2), considering the influence of the lagged value of GDP on the current GDP and the influence of FDI on GDP, from the VAR results, we see the influence of lagged value of GDP on the current value of GDP is based on only two time lags, while the coefficient of FDI, at the first level is statistically significant in the equation of GDP. The high explanatory power of the model of 0.997 gives satisfied explanation for the variation of the explanatory variables (GDPt-1, GDPt-2 and FDI), per unit variation of the dependent variable (GDP). In the model, the coefficient of FDI is statistically insignificant, pointing to low dependency level of the economic development from the foreign sources of capital, while the coefficient of GDP at the first and second lag is statistically significant at 5\% level of significance.

\subsection{Results from Wald-Granger causality test after VAR analysis}

In order to define the influence of GDP on FDI we employed a Granger causality analysis which should point out which occurrence proceeds the other, and vice versa, i.e. whether the FDI follow the changes of GDP, or vice versa the GDP follows the changes of FDI. The Granger causality analysis is done for other explanatory variable of FDI, specified in the model (1), like total school enrolment (TSE), openness (OP) and employment (EMP). A Wald test is commonly used to test Granger causality.

Table 4 Granger causality Wald tests for the relationship between FDI and GDP and the remaining indicators of the regression, namely employment, tertiary school enrolment and trade openness (dependent FDI)

Pairwise Granger causality tests

Date: 12/14/12 Time: 12:34

Sample: 1994Q1 2008Q4

Lags: 3

\begin{tabular}{lccc}
\hline Null hypothesis: & Obs & F-statistic & Prob. \\
\hline GDP_MIL_DOLL does not Granger cause FDI_IN_MIL_OF_US_DOL & 57 & 2.78131 & 0.0505 \\
FDI_IN_MIL_OF_US_DOL does not Granger cause GDP_MIL_DOLL & 0.07106 & 0.9752 \\
\hline EMPLOYMENT does not Granger cause FDI_IN_MIL_OF_US_DOL & 57 & 4.24189 & 0.0095 \\
FDI_IN_MIL_OF_US_DOL does not Granger cause EMPLOYMENT & 0.13244 & 0.9403 \\
\hline
\end{tabular}


Table 4 Granger causality Wald tests for the relationship between FDI and GDP and the remaining indicators of the regression, namely employment, tertiary school enrolment and trade openness (dependent FDI) (continued)

\begin{tabular}{|c|c|c|c|}
\hline Null hypothesis: & Obs & F-statistic & Prob. \\
\hline OPENNES does not Granger cause FDI_IN_MIL_OF_US_DOL & 57 & 1.84385 & 0.1512 \\
\hline FDI_IN_MIL_OF_US_DOL does not Granger cause OPENNES & & 2.70090 & 0.0555 \\
\hline TSE does not Granger cause FDI_IN_MIL_OF_US_DOL & 57 & 3.21536 & 0.0306 \\
\hline FDI_IN_MIL_OF_US_DOL does not Granger cause TSE & & 0.41727 & 0.7414 \\
\hline EMPLOYMENT does not Granger cause GDP_MIL_DOLL & 57 & 0.80510 & 0.4970 \\
\hline GDP_MIL_DOLL does not Granger cause EMPLOYMENT & & 0.27748 & 0.8414 \\
\hline OPENNES does not Granger cause GDP_MIL_DOLL & 57 & 4.58508 & 0.0065 \\
\hline GDP_MIL_DOLL does not Granger cause OPENNES & & 4.97978 & 0.0042 \\
\hline TSE does not Granger cause GDP_MIL_DOLL & 57 & 1.83207 & 0.1533 \\
\hline GDP_MIL_DOLL does not Granger cause TSE & & 0.41780 & 0.7410 \\
\hline OPENNES does not Granger cause EMPLOYMENT & 57 & 0.92021 & 0.4379 \\
\hline EMPLOYMENT does not Granger cause OPENNES & & 9.39672 & 5.E-05 \\
\hline TSE does not Granger cause EMPLOYMENT & 57 & 0.45385 & 0.7157 \\
\hline EMPLOYMENT does not Granger cause TSE & & 0.25645 & 0.8564 \\
\hline TSE does not Granger cause OPENNES & 57 & 10.9174 & 1.E-05 \\
\hline OPENNES does not Granger cause TSE & & 5.42250 & 0.0026 \\
\hline
\end{tabular}

Table 4 displays the results of the tests for the first equation where we test the Granger causality of FDI and GDP, and other indicators tested such as TSE, OP and EMP. The results are interpreted as follows:

1 After we regress FDI on its own lagged values and on lagged values of GDP and generate tests for the null hypothesis that the estimated coefficients on the lagged values of GDP are jointly zero. The first test is a Wald test that the coefficients on the three lags of GDP that appear in the equation for FDI are jointly zero. The null hypothesis that GDP does not Granger-cause FDI cannot be rejected, meaning that the GDP does not augment the level of FDI, which means that if the level of GDP increases in the Republic of Macedonia, the FDI will not follow. The evidence of the causality of GDP related to FDI has the same effect, meaning that if FDI increases GDP will not necessarily follow. Therefore, we accept the null hypothesis which states that FDI does not Granger-cause GDP. Based on the relationship we can conclude that GDP and FDI are statistically independent.

2 The second equation estimates the Granger causality of EMP and FDI. The null hypothesis that EMP does not Granger-cause FDI is rejected, meaning that if the level of EMP increases the level of FDI will follow. Furthermore, the evidence of the causality of FDI related to EMP cannot be rejected meaning that if FDI increases EMP will not necessarily follow. Among EMP and FDI we can say that unidirectional relationship exists from EMP to FDI. 
3 Similar results as the first estimation are found when testing for the relationship between OP and FDI. The null hypothesis that OP does not Granger-cause FDI cannot be rejected, meaning that the OP does not increase the level of FDI, which means that if the level of OP increases in the Republic of Macedonia, the FDI will not follow. This evidence of the causality of FDI related to OP has the same effect vice versa, meaning that if FDI increases OP will not necessarily follow. The relationship between OP and FDI are statistically independent.

4 The following equation estimates the Granger causality of TSE and FDI. The null hypothesis that TSE does not Granger-cause FDI is rejected, meaning that if the level of TSE increases the level of FDI will follow. Furthermore, the null hypothesis that FDI does not Granger-cause TSE cannot be rejected, thus if the level of FDI increases the TSE will not follow. Among TSE and FDI unidirectional relationship exists from TSE to FDI.

5 The null hypothesis that EMP does not Granger-cause GDP cannot be rejected, meaning that the EMP does not increase the level of GDP, which means that if the level of EMP increases in the Republic of Macedonia, the GDP will not follow. This evidence of the causality of GDP related to EMP has the same effect vice versa, meaning that if GDP increases EMP will not necessarily follow. Therefore, we say that these two variables are statistically independent.

6 The null hypothesis that OP does not Granger-cause GDP can be rejected meaning that we accept the alternative hypothesis which states that OP does Granger-cause GDP. If the level of OP increases the GDP will follow. The same effect is generated when estimating the effect of GDP on OP, meaning that the increase level of GDP will increase the level of OP in the Republic of Macedonia. Regarding the relationship between OP and GDP we conclude that feedback exist between OP and GDP.

7 Based on the results generate for the relationship between TSE and GDP we can accept the null hypothesis meaning that if the level of TSE increases the GDP will not follow. Vice versa the same effect is found between GDP and TSE, which means that there is no Granger causality between the two variables. Therefore we say that TSE and GDP are statically independent.

8 On the other hand the null hypothesis of the Granger causality between OP and EMP cannot be rejected; meaning that if the level of OP increases the EMP will not necessarily follow. On the other hand the null hypothesis that EMP does not Granger-cause OP is rejected. Therefore, we accept the alternative hypothesis that EMP does cause OP, meaning that if the level of EMP increases the openness will follow. So, for the relationship between OP and EMP we can say that unidirectional relationship exists from EMP to OP.

9 Based on the results generate for the relationship between TSE and EMP we can accept the null hypothesis meaning that if the level of TSE increases the EMP will not follow. Vice versa the same effect is found between EMP and TSE, which means that there is no Granger causality between the two variables. Hence, the relationship between the variable of TSE and EMP are shown to be statistically independent. 
10 The null hypothesis that TSE does not Granger-cause OP can be rejected meaning that we accept the alternative hypothesis which states that TSE does Granger-cause OP. If the level of TSE increases the OP will follow. The same effect is generated when estimating the effect of OP on TSE, meaning that the increase level of OP will increase the level of TSE in the Republic of Macedonia. Thus, regarding the relationship between TSE and OP, we conclude that feedback exists among them.

Out of the general conclusions it is evident that despite the above-average growth rates in both GDP and FDI in the country we have found that GDP does not seem to induce FDI and likewise, FDI seems not to induce GDP. It is possible that the nature of this relationship is influenced by other institutional and economic factors, some of which we explore in the next section.

\section{Conclusions}

One of the major objectives of this study was to examine, if there is any long run economic relationship between FDI and other variables used in this study by applying the cointegration analysis and ECM. The research further attempts to investigate the effect of FDI on economic development of the Republic of Macedonia using the methodology of VAR and Granger causality test. The findings of the study indicate that data analysis is well suited for our study and provides important results.

Out of the general conclusions it is evident that despite the above-average growth rates in both GDP and FDI in the country, we have found that GDP does not seem to induce FDI and likewise, FDI seems not to induce GDP. It is possible that the nature of this relationship is influenced by other institutional and economic factors.

Furthermore, we have found the evidence that, FDI indirectly increases GDP though trade openness, namely export by interactive relations between exports and GDP. This finding is consistent with findings of Hsiao and Hsiao (2006), and to be more specific, our results also support the Bhagwati (1978) hypothesis that "the gain from FDI are likely far more under an export promotion (EP) regime than an import substitution (IS) regime". The priority of a developing country for the economic growth policy, in general, appears to be to open the economy for inward FDI under the export promotion regime, and then the interaction between exports and GDP will induce economic development.

Whether FDI leads to economic development is still an arguable issue. The relationship is not the same for each country; in contrary it will differ between countries making it important or unimportant depending on the country under study, nature of investments, the policy implementation of the host country, the methodology used, and the period of study.

So, based on the findings we can conclude that external economic relations have an important role in countries such as the Republic of Macedonia, because of two main reasons. Initially, the Republic of Macedonia is a relatively small country, and due to that fact the Republic of Macedonia is not rich with natural recourses of different kinds and this makes our country dependent on imports of many row materials.

Moreover, the positive benefits associated with foreign investments such as imports of capital, new technology, know-how, management skills and expertise, appear to be vital components in the process of the economic development of the Republic of Macedonia. 
Export-oriented investment by foreign direct investors should make a significant contribution to enhance overall export performance in order to fully unlock the potential of Macedonian exporters. On the other hand, Macedonian companies in order to increase their presence in international markets should be more proactive and accomplish considerable developments in the competitiveness and innovations of the product and services they offer. In general companies operating in the Republic of Macedonia should develop the right product for the international market rather than try to find the right markets for Macedonian product internationally.

In addition, it has been verified by some East Asian economies in the second half of the 20th century or Ireland over the last two decades that strong export orientation can be a powerful engine of economic growth. In this regard, sustainable growth of the Macedonian economy should be export based, since the positive effect of trade driven expansion in market size for a small country is greater than it is for a large country (Kathuria, 2008).

As mentioned earlier FDI is believed to transfer technology, promote learning by doing, train labour and in general, results in spillovers of human skills and technology. Several conditions are required for all this to hold in a given economy. Therefore, it is imperative for national governments to create favourable environment for FDI to flow in and do their best.

For FDI to be a significant contributor to economic growth, the Republic of Macedonia would do better by focusing on improving infrastructure, human resources, developing local entrepreneurship, creating a stable macroeconomic framework and conditions conducive for productive investments to speed up the process of development.

In general, to improve the investment climate and increase the benefits of FDI inflows, the following recommendations should be taken into consideration:

- Continue work to maintain a stable macroeconomic environment and reduce market distortion. Big swings in economic activity, high inflation, unsustainable debt levels and volatility in exchange rates and financial markets can all contribute to job losses, increasing poverty and divert foreign capital to other countries.

- Introduce new procedures to assist the integration of foreign companies into the domestic economy.

- Reassure that legislation has a clear and unique interpretation.

- Speed up the implementation of new laws and amendments to existing legislation.

- Improve the business climate and target future efforts to attract FDI in export-oriented industries.

- Take measures to fight bureaucracy, corruption and red tape, including establishing a powerful, independent supervisory authority.

- Develop a quality infrastructure.

- Maintain investment incentives to be non-distorting, transparent and mixed.

- Encourage the participation of the private sector and work on changing negative cultural perceptions of privatisation. 
All these recommendations will contribute on the enhancement of the economic efficiency and productivity of the Macedonian economy. This paper has important implications for policy makers in the European Union but also other parts of the world as it demonstrates the importance of FDI to a countries economic growth rate. Policy makers need to include the suggestions raised in this paper that the focus on entrepreneurship is paramount to successful internationalisation taking place and can lead to greater societal benefits for a country. Future research should continue to investigate the role of FDI in transition economies by comparing the economic growth rate of Macedonia with other countries to see how government policy interventions can help increase internationalisation rates. More empirical work like the data analysed in this paper would be useful to see how international entrepreneurship is an important component of political and social discussions.

\section{References}

Agarwal, S. and Ramaswami, S.N. (1992) 'Choice of foreign-market entry mode - impact of ownership, location and internalization factors', Journal of International Business Studies, Vol. 23, No. 1, pp.1-27.

Aitken, B.J., Hanson, H.G. and Harrison, A.E. (1997) 'Spillovers, foreign investment and export behavior', Journal of International Economics, Vol. 43, No. 1, pp.103-132.

Aizenman, J. (2005) 'Opposition to FDI and financial shocks', Journal of Development Economics, Vol. 77, pp.467-476.

Akaike, H. (1969) 'Fitting autoregressive models for prediction', Annals of the Institute of Statistical Mathematics, Vol. 21, No. 1, pp.243-247.

Anandakumar, K. (2012) 'FDI inflows in India: a comparative analysis with special reference to services sector, telecommunications sector and computer hardware and software sector', International Journal of Business and Globalisation, Vol. 9, No. 2, pp.186-194.

Andersen, O. (1993) 'On the internationalization process of firms - a critical analysis', Journal of International Business Studies, Vol. 24, No. 2, pp.209-231.

Bajo-Rubio, O. and Sosvilla-Rivero, S. (1994) 'An econometric analysis of foreign direct investment in Spain', Southern Economic Journal, July, Vol. 61, No. 1, pp.104-120.

Bhagwati, J. (1978) Anatomy and Consequences of Exchange Control Regimes, Balinger Publishing Company, Cambridge, Massachusetts.

Bhensdadia, R.R. and Dana, L.P. (2004) 'Globalisation and rural poverty', International Journal of Entrepreneurship and Innovation Management, Vol. 4, No. 5, pp.458-468.

Blomström, M. (1986) 'Foreing investment and productive efficincy: the case of Mexico', The Jurnal of Industrial Economics, Vol. 35, No. 1, pp.97-110.

Blomstrom, M., Lipsey, R.E. and Zejan, M. (1994) What Explains Developing Country Growth, NBER Working Paper No. 4132, Cambridge, MA.

Carkovic, M. and Levine, R. (2002) Does Foreign Direct Investment Accelerate Economic Growth?, 28 August 2002, Working Paper, Department of Finance, University of Minnesota.

Caves, R.E. (1996) Multinational Enterprise and Economic Analysis, Cambridge University Press, Cambridge.

Chowdhury, A. and Mavrotas, G. (2006) 'FDI and growth: what causes what?', World Economy, Vol. 29, No. 1, pp.9-19.

Dauti, B. (2009) Determinants of Foreign Direct Investment in Macedonia. Evidence from Time Series 1994-2008 [online] https://ideas.repec.org/h/pkk/sfyr09/41-55.html (accessed 30 January 2015). 
De Gregorio, J. (1992) 'Economic growth in Latin America', Journal of Development Economics, Vol. 39, No. 1, pp.58-84.

Engle, R.F. and Granger, C.W.J. (1987) 'Co-integration and error correction: representation, estimation, and testing', Econometrica, Vol. 55, No. 2, pp.251-276.

Estrin, S. and Uvalic, M. (2014) 'FDI into transition economies', Economics of Transition, Vol. 22, No. 2, pp.281-312.

Falk, N. (2009) 'Impact of foreign direct investment on economic growth in Pakistan', International Review of Business Research Papers, September, Vol. 5, No. 5, pp.110-120.

Frimpong, J.M. and Oteng-Abayie, E.F. (2008) 'Bivariate causality analysis between FDI inflows and economic growth in Ghana', Internatinal Research Journal of Finance and Economics, May, MPRA Paper No. 15, p.103.

Globerman, S. (1979) 'Foreign direct-investment and spillover efficiency benefits in Canadian manufacturing industries', Canadian Journal of Economics - Revue Canadienne D’economique, Vol. 12, No. 1, pp.42-56.

Granger, C. (1969) 'Investigating casual relationship by econometric models and cross sprectal methods', Econometrica, Vol. 37, No. 3, pp.424-458.

Gujarat, D. (2003) Basic Econometrics, McGraw-Hill, Inc., New York.

Haddad, M. and Harrison, A. (1993) 'Are there positive spillovers from direct foreign investment? Evidence from panel data for Morocco', Journal of Development Economics, Vol. 42, No. 1, pp.51-74.

Hansen, H. and Rand, J. (2006) 'On the causal links between FDI and growth in developing countries', The World Economy, Vol. 29, No. 1, pp.21-41.

Hsiao, C. (1981) 'Autoregressive modelling and money-income causality detection', Journal of Monetary Economics, Vol. 7, No. 1, pp.85-106.

Hsiao, F.S.T. and Hsiao, M.C.W. (2006) 'FDI, exports, and GDP in East and Southeast Asia-panel data versus time-series causality analysis', Journal of Asian Economics, Vol. 17, No. 6, pp.1082-1106.

Johnson, A. (2006) The Effects of FDI Inflows on Host Country Economic Growth, CESIS Working Paper Series, Royal Institute of Technology, Sweden.

Jyun-Yi, W. and Hsu, C.C. (2008) Does Foreign Direct Investment Promote Economic Growth? Evidence from a Threshold Regression Analysis [online] https://ideas.repec.org/a/ebl/ecbull/ eb-08o10014.html (accessed 30 January 2015).

Kathuria, S. (Ed.) (2008) Western Balkan Integration and the EU: An Agenda for Trade and Growth, Workd Bank, Washington, DC.

Kokko, A. (1994) 'Technology, market characteristics, and spillovers', Journal of Development Economics, Vol. 43, No. 2, pp.279-293.

Kurtishi-Kastrati, S. (2012) The Impact of Foreign Direct Investment on the Economic Development of Macedonia, PhD Thesis, South-East European University, Tetovo.

Lankes, H-P. and Venables, J.A. (1996) 'Foreign direct investment in economic transition: the changing pattern of investments', Economics of Transition, Vol. 4, No. 2, pp.331-347.

Madura, J. (1989) International Financial Management, West Publishing Company, USA.

Mohnot, R. (2007) 'Changing pattern of foreign direct investment (FDI) in Asian region: issues, motives and strategies for economic development', World Review of Entrepreneurship, Management and Sustainable Development, Vol. 3, No. 2, pp.158-169.

Nandi, S. (2011) 'A note on foreign direct investment and Indian economy', World Review of Entrepreneurship, Management and Sustainable Development, Vol. 7, No. 1, pp.98-107.

Nayak, A.K.J.R. (2005) 'FDI model in emerging economies: case of Suzuki Motor Corporation in India', Journal of American Academy of Business, Vol. 6, No. 1, pp.238-245.

Ramadani, V., Rexhepi, G., Gërguri-Rashiti, S., Ibraimi, S. and Dana, L-P. (2014) 'Ethnic entrepreneurship in Macedonia: the case of Albanian entrepreneurs', International Journal of Entrepreneurship and Small Business, Vol. 23, No. 3, pp.313-335. 
Rappaport, J. (2000) How does Oppenes to Capital Flow Affect Growth?, Federal Reserve Bank of Kansas City, Research Working Paper.

Ratten, V., Dana, L-P., Han, M. and Welpe, I. (2007) Internationalisation of SMEs: European comparative studies', International Journal of Entrepreneurship and Small Business, Vol. 4, No. 3, pp.361-379.

Sathe, S. and Handley-Schachler, M. (2006) 'Social and cultural factors in FDI flows: evidence from the Indian states', World Review of Entrepreneurship, Management and Sustainable Development, Vol. 2, No. 4, pp.323-334.

Sohinger, J. and Horvatin, D. (2005) 'Foreign direct investment and competitiveness in transition economies: the case of Croatia', International Journal of Entrepreneurship and Small Business, Vol. 2, No. 3, pp.266-282.

Toda, H. and Yamamoto, T. (1995) 'Statistical inference in vector autoregressions with possible integrated processes', Journal of Econometrics, Vol. 66, Nos. 1/2, pp.225-250.

United Nations (1993) Admission of the State Whose Application is contained in Document A/47/876-S/25147 to Membership in the United Nations [online] http://www.un.org/ documents/ga/res/47/a47r225.htm (accessed 22 November 2012).

World Investment Report (2008) Transnational Corporations and the Infrustructure Challenge, UNCTAD, Geneva.

Zhang, K.H. (2001) 'How does foreign direct investment affect economic growth in China?', Economies of Transition, Vol. 9, No. 3, pp.679-693.

\section{Notes}

http://elibrary-data.imf.org/finddatareports.aspx?d=33061\&e=169393.

http://www.stat.gov.mk/Default_en.aspx.

http://www.nbrm.mk/default-en.asp.

4 According to the International Monetary Fund, Macedonia belongs to this group. 